\title{
8-Prenylnaringenin from hop (Humulus lupulus L.) - a panacea for menopause?
}

\author{
ALDONA MINECKA*, MARIA ZYCH, ILONA KACZMARCZYK-SEDLAK
}

\author{
Department of Pharmacognosy and Phytochemistry \\ Medical University of Silesia in Katowice \\ School of Pharmacy with Division of Laboratory Medicine in Sosnowiec \\ Jagiellońska 4 \\ 41-200 Sosnowiec, Poland
}

*corresponding author: aldona.minecka@med.sum.edu.pl

\begin{abstract}
Summary
8-Prenylnaryngenin (8-PN) is the strongest known phytoestrogen (PE). Its main source is the female inflorescences of hops (Humulus lupulus L.). 8-PN, which, in contrast to other PEs, is proven to have stronger activity and higher affinity for the $\alpha$ subtype of estrogen receptor (ER). Therefore, it may be an effective substitute for hormone replacement therapy (HRT). The studies in postmenopausal women have shown its particular effectiveness in reducing hot flashes. However, a strong stimulation of uterus by 8-PN may be associated with the occurrence of adverse effects (eg. bleeding) and increase the risk of carcinogenesis. The H. lupulus extracts preparations are currently supplements which makes control of the doses used and thus increases the occurrence of uncontrolled self-treatment difficult. This paper presents the current knowledge on 8-PN and discusses the potential risks associated with use of hops to alleviate the symptoms of menopause.
\end{abstract}

Key words: 8-prenylnaringenin, hop, phytoestrogens, menopause, hot flashes, dietary supplements, side effects

\section{INTRODUCTION}

Hop (Humulus lupulus L.) plant family Cannabaceae is an essential raw material used in brewing. The main parts used in medicine are the whole female inflorescences called cones. They are covered fibers, producing the yellow secretion - lupulin, rich in various substances. In addition to the essential oil, resin and tannins, hop cones also contain bitter acids which are responsible for the bitter taste and characteristic aroma of beer $[1,2]$. In medicine, hop is a component of preparations used to relieve nervous tension, insomnia, anxiety and digestive problems $[1,2]$. Hop extracts also show the estrogenic 
activity, thus they are used supplementary in the gynecological disorders [1-3]. This action is caused by the flavonoids present in the hop extracts. One of them is 8-prenylnaringenin (8-PN), which is being considered to be the most powerful phytoestrogen (PE) [4]. Apart from 8-PN, the estrogenic properties (although weaker) are shown in 6-prenylnaringenin (6-PN), 6,8-diprenylnaringenin and 8-geranylnaringenin $[4,5]$. Other hop flavonoids include xanthohumol (XH - prenylated chalcone, the richest), isoxanthohumol (IX), desmethylxanthohumol (DMX) and 6-prenylnaringenin (6-PN, isomer of 8 -PN) [1-3]. The presence of 8-PN has currently led to the wide usage of the hops in the production of dietary supplements to alleviate the symptoms of menopause in women, being particularly effective in reducing hot flashes $[6,7]$. It is also a component of preparations for "breast enlargement" $[3,5]$. Estrogenic properties and the potency of the 8-PN, which exceeds the already known PEs (eg. genistein and daidzein from soy or clover), make the hop a good alternative to HRT $[7,8]$.

Hormone replacement therapy (HTR) not only alleviates menopausal discomfort but it also prevents osteoporosis caused by a lack of endogenous estrogen [6]. To prevent the proliferation of endometrial cells after the administration of estrogen in women with an intact uterus, it is necessary to add progestins to the composition of the HTR [9]. The need to search for the alternative therapies for HTR appeared as a result of a few alarming reports which proved that the hormone therapy may increase the incidence of breast cancer and cause thromboembolism, strokes, dementia and other life-threatening complications $[6,9,10]$. In addition, they carry side effects, such as abnormal bleeding, breast tenderness, weight gain and fatigue [1]. In spite of the risk of adverse reactions (caused by the progesterone component and increasing dose of estrogens), HTR is still recommended as the most effective in treating vasomotor disorders, preventing osteoporosis and protecting the cardiovascular system, especially when it is applied before 60 years of age, or during the first decade of the last menstrual period [6]. However, the aforementioned studies have contributed to the growing popularity of PEs which, due to their natural origin, are considered to be safer and free of adverse effects [10].

Despite the effectiveness of the use of PEs, there is a possibility of the side effects that are associated primarily with endometrial hyperplasia, the risk of bleeding (as consequences of the prolonged, uncontrolled PEs treatment) $[9,10]$. This is a particularly important issue concerning the potent 8 -PN. It is difficult to assess the negative impact, due to the lack of clinical trials and insufficient control during the production of supplements [3]. The aim of this paper is to present the current knowledge on the 8-PN and the consequential assessment of the efficacy and safety of this compound in the context of menopausal disorders.

\section{Phytoestrogens}

PEs are plant compounds of nonsteroidal structure which, because of its similarity to $17-\beta$-estradiol have estrogenic properties by interaction with estrogen receptors [11]. They may operate according to the mechanism of genomic (influence on the expression of certain genes responsible, among other things, for proliferation, or apoptosis) and non-genomic (eg. inhibiting enzymes such as aromatase). PEs include polyphenolic compounds, whose structure consists of one to several aromatic rings with multiple hydroxyl groups [10]. Polyphenols classified as PEs are lignans (secoisolariciresinol, matairesinol, pinoresinol, and lariciresinol eg. in flax seed), stilbenes (resveratrol eg. in grapes) and flavonoids. Among flavonoids which are PEs are distinguished isoflavones (eg. genistein, daidzein, glycitein, and formononetin from soy or red clover), coumestans (coumestrol eg. in the soy, red clover) and flavanones (naringenin, 6-prenylnaringenin, 8-prenylnaringenin from hop) $[10,12,13]$. The active forms of the most popular PEs from the isoflavones group interact mainly with the $\beta$ subtype of ER, unlike 8 -PN, which strongly binds to a subtype of $E R \alpha[5,12,13]$. It has been shown that the supplementation of PEs (especially soy isoflavones) has a positive influence on the quality of life in postmenopausal women by reducing the sleep disorders and improving memory, inhibiting bone resorption and protecting the cardiovascular system (i.a. the beneficial effect of soybean lipid profile). Apart from the estrogenic activity, the additional benefits are brought by the characteristic properties of polyphenols (especially flavonoids), active antioxidant and anticarcinogenic [11-13].

\section{Menopause symptoms and causes of hot flashes}

According to World Health Organization, menopause is the permanent cessation of menstruation resulting from the loss of ovarian follicular activity [9]. The perimenopausal period is natural biologic 
process connected with ageing and occurs at the age about 45-50. The first symptoms associated with menopause can be observed when the ovarian secretory function declines, and estrogen level (mostly 17 - $\beta$-estradiol) in the blood decreases. The symptoms persist for several years after the last menstruation $[9,14,15]$. The estrogen deficiency leads to the imbalance in hormonal economy, which, in turn, can contribute to the development of many metabolic diseases. The prolonged lack of estrogen can cause cardiovascular disease, osteoporosis, osteoarthritis, degenerative disc disease, obesity, lipid disorders, impaired glucose tolerance, insulin resistance, hyperinsulinemia, type 2 diabetes and hypertension but also pain of join $[14,16]$. It also affect the urogenital system leading to inflammation, atrophic changes develop, discomfort or urinary incontinence $[15,16]$. Vasomotor symptoms (hot flashes, severe sweating, sleep disorders) appear earlier, several years before the last bleeding $[15,16]$. There are also non-specific symptoms, such as behavioral alterations (anxiety, depression, bad mood, lack of concentration, apathy, loss of libido, sleep disorders) $[9,14,16]$ and somatic discomforts (dizziness, headache, muscle and joint pain) [15-17]. The vasomotor symptoms experienced by women in menopausal period can be very nagging especially, hindering their functioning and thus requiring treatment.

Hot flashes are the most common symptoms of menopause and affecting over $80 \%$ of females. This symptoms could be mild, moderate or severe. [9, $14,18]$, while the bouts of hot flashes are short and sharp. Hot flashes are the most frequently reported menopausal complaints, which intensify bad mood, depression and decline quality of life, thus require effective measures for treatment.

The cause of hot flashes seems to be poorly understood. Estrogens mechanism of negative feedback inhibit the secretion of $\mathrm{GnRH}$ (gonadotropin-releasing hormone) in the hypothalamus and thereby reduce the release of LH (luteinizing hormone) by the pituitary and its level in the serum $[9,19]$. The lack of estrogen disturbs the balance between the transmitters in the central nervous system (CNS) (eg. noradrenaline, dopamine, serotonin). The excess of noradrenalin strongly stimulates $\mathrm{GnRH}$ pulse generator and promotes the secretion of gonadotropins [9]. These signals can interfere with the thermoregulatory center located nearby in the anterior hypothalamus and neural pathways regulating heart rhythm. A disturbance in normal thermoregulation (i.a. by changing the conductivity of the skin and lowering the threshold for sweating) has been also observed $[9,19,20]$.
Moreover, a sudden feeling of heat on the face and trunk with redness of the skin, followed by the intense sweating (may also appear: a rapid heart rate, weakness or irritability) occurs. In addition, central nervous system (CNS), in the mechanism of the formation of hot flashes may participate in the peripheral regulation by ERs arranged in blood vessels (eg. ER $\alpha$ in aorta and uterine vessels) [20].

\section{8-Prenylnaringenin - characteristics and me- chanism of action}

The fraction of estrogenic activity from $H$. lupulus is obtained mostly from hydroalcoholic extraction of spent hops after the extraction of bitter acids (with supercritical or liquid carbon dioxide) [7, 21, 22]. Among the flavonoids, the substances which are proven to be the most important for hormonal activity are flavanones (isoxanthohumol, 6-PN, 8-PN, 6-geranylnaringenin or 6,8-diprenylnaringenin) and chalcones (xanthohumol - XN, and desmethylxanthohumol - DMX) [10], which are intermediates in the biosynthesis of flavonoids. Prenylated derivatives of flavanones (like 8-PN) are secondary metabolites of plants and protect plants against pathogens, pests and environmental stress. 8-PN (fig. 1) shows strong estrogenic activity due to the presence of prenyl group at position $\mathrm{C} 8$ by site-specific hydrophobic van der Waals interactions with ERs [7, 23].

In currently conducted in vitro and in vivo studies, investigated hop extracts have been standardized according to 8 - $\mathrm{PN}[1,2,21]$. 8-PN similar to the endogenous $17-\beta$-estradiol binding to ERs and in vitro showed the strongest estrogenic activity among the PEs [4]. It is 10 -fold more potent than coumestrol and 100-fold more potent than genistein [24].

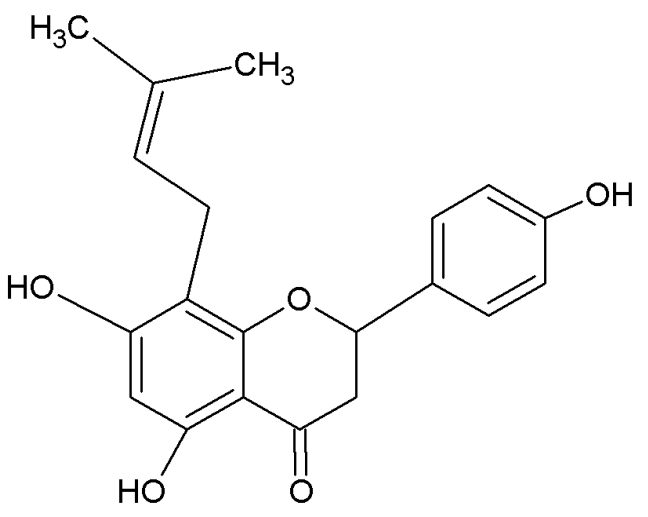

Figure 1.

8-Prenylnaringenin - chemical structure 
ERs are intracellular structures belonging to nuclear receptors, their endogenous ligand is 17 - $\beta$-estradiol (E2). After E2 binding, they are dimerized, migrate to the nucleus and bind to DNA in the areas called estrogen responsive elements (EREs). Followed by attachment of the respective coactivators or corepressors, the mRNA transcription and protein synthesis takes place, which causes the effect of ER stimulation $[25,26]$. There are two subtypes of ERs: $\alpha$ and $\beta$, which are distributed in varying concentrations, in various tissues and mediate many physiological processes. The activity of the agonist/antagonist in addition to the distribution of ERs and the concentration of compound is related to the structure of ligand $[25,26]$. Both ER subtypes occur in reproductive tract, vascular endothelium, smooth muscles, myocardial cells, and central nervous system (CNS). ER $\alpha$ prevail in the breasts, liver, uterus, hypothalamus and pituitary and bones, while $\operatorname{ER} \beta$ are located preferentially in intestine, lung, prostate, testis, ovary, the urogenital system, blood vessels as well as in hypothalamus [1, 26, 27]. 8-PN is a pure agonist ER (in vitro study) and strongly competes with E2 for the receptors. It has high affinity for both ER subtypes, but is a 2-3fold greater in estrogenic activity relative to the ER $\alpha$ (in contrast to known PEs, that preferentially bind to $\operatorname{ER} \beta)[1,5,24,27,28]$. In order to produce the effect of stimulation, the agonist must cause a formation of a hydrophobic cleft within ER. Pockets binding ligands for $\operatorname{ER} \alpha$ and $\operatorname{Er} \beta$ are of different size and flexibility. Binding site inside $\operatorname{ER} \beta$ is lower than $\operatorname{ER} \alpha$, hence the bond and the formation of stable conformation of 8-PN may be more difficult [26, 29].

8 - $\mathrm{PN}$ is present as a racemic mixture of two enantiomers $2 \mathrm{~S}(-) 8-\mathrm{PN}$ and $2 \mathrm{R}(+) 8-\mathrm{PN}$, while the majority of the natural flavanones predominates isomer $\mathrm{S}$. The lupulin glands of hops do not contain chalcone isomerase. Both enantiomers have similar bioactivity with high selectivity to the ERs, although it has been shown that the form of $2 \mathrm{~S}(-)$ has generally greater affinity for the ERs $[24,25]$.

Studies on cells expressing ER (mainly transfected yeast cells or Ishikawa cells - human endometrial adenocarcinoma epithelial cells) and in animals (mainly in rats) not only have shown the similarities between the E2 but also proved that the strength of 8 - $\mathrm{PN}$ is similar to the natural estrogen. The affinity of E2 to the ER is from 10- to 100 -fold less, and in vivo activity is even 20000 times lower [1, 2, 24, 28]. In vitro 8-PN can also increase the amount of progesterone receptor mRNAs in the range similar to E2 [8]. Furthermore, studies have demonstrated that 8 -PN is the first naturally occurring selective estrogen receptor modulator (SERM). SERMs are agonists or antagonists, depending on the tissue which determines it [30, 31]. 8-PN has a higher selectivity for ER $\alpha$ in bones than E2 for this receptors in uterus [20, 24, 28]. 8-PN exceeds the blood brain barrier and similarly to estrogen affects the endocrine effects attributable to the hypothalamic-pituitary system $[20,28]$. This is responsible for the effectiveness of 8-PN therapy for menopause, primarily due to its ability to relieve the symptoms of hot flashes [9].

Another feature of 8-PN is the ability to inhibit angiogenesis, to stimulate cell adhesion, the inhibition of cytochrome P450 enzymes responsible for, i.a. activation of some aflatoxin and anti-fungal properties [7, 32]. Both 8-PN and XN act as chemopreventors, mostly due to antioxidant mechanisms $[30,31]$.

\section{Pharmacokinetics and pharmacodynamics of 8-prenylnaringenin}

In dry, female hop cones, the amount of 8 - $\mathrm{PN}$ is lower than XN (up to 100-fold less) and IX (10- to 30 -fold) [30, 31, 33]. However, the larger amounts of the powerful 8-PN result from the transformation of other flavonoids of hop. Figure 2 shows reactions that can increase the concentration of 8 -PN in living organism. A direct source of $8-\mathrm{PN}$ in the system is DMX, which is cyclized to 8-PN, while DMX may also proceed from XN $[1,21,31$, 34]. Second main precursor of 8-PN is IX. XN under the influence of temperature or acidic gastric juice undergoes cyclization to the IX $[8,30,31]$. The reaction of O-demethylation of IX leading to the formation 8-PN is catalyzed by the microsomal cytochrome P450 isoform 1A2, or it occurs as a result of the action of intestinal microflora (proved in animal study) $[30,31,34]$. The conversion in gut may increase the exposure to 8-PN even by 10 fold (study with incubation of fecal samples from healthy volunteers with hop flavonoids). The experience in a model simulating the human gastrointestinal sections showed that the aforementioned compounds pass unchanged through the alimentary tract, and most of the reactions takes place in the distal part of the large intestine [33]. The efficiency of these reactions in intestines and in liver strongly depended on the individual composition of the microflora and individual variability. Genetic differences in the activity of specific isoform of CYP 450 may also increase the risk of interactions hop 
<smiles>COc1cc(O)c(CC=C(C)C)c(Oc2cc3c(cc2O)OC(c2ccc(O)cc2)CC3=O)c1C(=O)C=Cc1ccc(O)cc1</smiles>

Figure 2.

Transformation of hop flavonoids to 8-PN. (Description in the text). XN - xanthohumol, DMX - desmethylxanthohumol, IX - isoxanthohumol, 6-PN - 6-prenylnaringenin, 8-PN - 8-prenylnaringenin

supplements with drugs. Hop extracts in low concentrations potently inhibit the microsomal enzymes of the family 2C (especially 2C19, 2C9 and $2 \mathrm{C} 8$ ) and subtype 1A2. This can inhibit the metabolism and increase the harmful effects of some drugs, eg. statins, warfarin, certain non-steroidal anti-inflammatory drugs or paracetamol, imipramine and xanthines [35].

Studies on pharmacokinetics and pharmacodynamics of 8-PN which carried out on healthy postmenopausal women with increasing doses of 8-PN (50 $\mu \mathrm{g}, 250 \mu \mathrm{g}$ and $750 \mu \mathrm{g}$ ) [28] are administrated and the other volunteers were treated for five days, at monthly intervals, with the increasing doses of a hop extract containing 8-PN, 6-PN, IX, and XN [30]. The low oral bioavailability is associated with absorption and conjugation occurring both in the liver and the intestines. XN easily accumulates within the intestinal cells and binds to protein, so it can form a kind of reservoir of material for the production of 8-PN (moreover concentration of 8-PN increased after about one day of administration) [31]. 8 - $\mathrm{PN}$ is absorbed in the intestines, the blood reaches the liver, there is mainly conjugation with glucuronic acid. Subsequently, the bile enters the intestine, where it is reabsorbed from partial deconiugation in the mechanism of enterohepatic recirculation. This effect is responsible for the long half-life (over $20 \mathrm{~h}$ ) and two-fold increase in the maximum serum concentration (about $2 \mathrm{~h}$, and approx. 5-8 h) $[28,30]$. The metabolism includes the coupling reactions to form the glucuronide and sulfate. Elimination takes place mainly in faeces. It was detected that 8-PN has 12 metabolites which are produced mainly in the 
liver, as a reaction within a ring system and prenyl group $[32,36]$. Tests with the enzyme obtained from human microsomes revealed that the most abundant metabolites are the cis and trans alcohols formed by hydroxylation in the prenyl chain (which show the property of estrogenicity 10 times less than 8 -PN) $[8,32]$. Estrogenic properties have also metabolites with alcohol and ketone group [36] and compound obtained by the desaturation central ring (6-prenylapigenin) [32].

\section{8-Prenylnaringenin and menopausal symp- toms - animal studies}

Potentially beneficial effect of 8-PN is a result of its selectivity for the subtype of the ERa. Therefore, bone tissue, uterus, mammary glands, adipose tissue and the hypothalamus are the most visible site of the efficiency of this compound $[1,26,27]$. However, an excessive postmenopausal uterine (and the whole urogenital tract) or breast tissue stimulation can cause various side effects, eg. unexplained bleeding, hyperplasia and even the development of cancer [3]. The tissue specificity to bones is the reason why that 8 - $\mathrm{PN}$ may help to prevent the occurrence of the osteoporosis caused by ceasing of the secretory function of the ovaries during menopause, as well as decreasing levels of natural estrogen, which prevents an excessive bones resorption. The studies in animal models of osteoporosis induced by ovariectomy have shown that the subcutaneously administered 8-PN (0.67, 1.77 and $18 \mathrm{mg} / \mathrm{kg} /$ day) increases bone mineral density (BMD), compared with the control group [25]. At the same time, it does not have a significant effect on the uterus weight and endometrium (10 times weaker than E2). In this study, rats received three increased doses of the $2 \mathrm{~S}$ (-) 8-PN by 28 days (the highest $18 \mathrm{mg} / \mathrm{kg}$ body weight), but this isomer in vivo showed no difference in the activity and potency in respect to the reacemic mixture of 8-PN [25].

The promising results for the prevention of obesity and postmenopausal, cardiovascular diseases were obtained in ovariectomized rats, treated for 3 months with two oral doses of 8-PN. Higher dose of $8-\mathrm{PN}(68.4 \mathrm{mg} / \mathrm{kg}$ body mass) caused a decrease in body weight, reduction in total cholesterol and the LDL fraction, without affecting the HDL and triglycerides. The activity profile of 8 -PN was more favorable than E2, as the E2 causes a decrease in HDL [27]. Although the dose of 8-PN used in that experiment were 10 times higher than the analogous in terms of the effect of dose E2, it proved the similarity of action of both substances on the hypothalamus and pituitary. The similarity detected in animal studies demonstrated that higher doses of 8-PN reduce serum concentration LH and FSH (follicle-stimulating hormone), and increase the level of prolactin. The higher concentration of complement protein $\mathrm{C} 3$, which is a marker of stimulation of ER $\alpha$, is proof of the presence of ER $\alpha$ in the central nervous system (CNS) [19].

The animal studies have not shown a clear cause - effect relationship between the amount of GnRH, $\mathrm{LH}$ and FSH after using 8-PN, because the decline in LH and FSH after the action on the pituitary response did not cause any change in the amount of GnRH in the hypothalamus [19]. This observation is confirmed by a decrease in tail skin temperature (TST) in ovariectomized rats after oral $(7.5 \mathrm{mg} / \mathrm{kg})$ and subcutaneous $(400 \mu \mathrm{g} / \mathrm{kg})$ administration of 8-PN. The observation of the TST increase after ovariectomy are carried out by means of the animal model used for the study of hot flashes. The appropriate peripheral ER antagonists inhibited the decline of TST [20].

8-PN has estrogenic profile of action and is more selective compared to $\mathrm{ER} \alpha$, therefore, similarly to endogenous estrogen, it can produce the effect of stimulation in the uterus, breast and vagina. This is potentially the greatest disadvantage of this substance and may limit the use of hop extracts in the treatment of symptomatic menopause. Utherotropic effect, increasing the number of mitoses and leakage of radiolabelled albumin in permeability acute in vivo test (a result of a fast vascular response of the endometrium) was observed after the administration of 8 -PN $[4,5]$. The experiment on ovariectomized rats showed an increase in wet uterine weight after the administration of 8-PN and E2. In the threemonths experiment, in which animals were provided with 8-PN (doses 6.77 and $68.42 \mathrm{mg} / \mathrm{kg}$ body weight) and E2 (0.17 and $0.7 \mathrm{mg} / \mathrm{kg}$ body weight) with food, only the higher dose of 8-PN had effects similar to estrogen [37]. Estrogens stimulate the growth of the endometrium during the menstrual cycle in the preparation to receive a fertilized ovum. The low dose of 8-PN increased slightly the height of the endometrium, a higher dose would cause hypertrophy and hyperplasia of cells, similar to the higher dose E2 [37]. In contrast, E2 showed no signs of metaplasia, anaplasia, or highly increased number of mitoses. Also 8-PN does not extend cervix and reduces the purulent bacterial infections. However, the 8-PN stimulated the formation of polyploid structures in the form of myomas. Both doses of 
E2 and high dose 8-PN increased the expression of the progesterone receptor and stimulated the mammary glands to secrete exudation [37]. It was agreed that rats need 10-15-fold higher dose of the drug to achieve the effect similar to that of human, because the metabolism process in rats is faster $[8,37]$. Hence, the similar effects in human can achieved at 10 -fold lower doses and there is a risk that the effect on the uterus and breast can be dangerous even in minor doses of 8-PN.

\section{The effectiveness of 8-prenylnaringenin in alle- viating symptoms of menopause in women}

The results of several randomized, clinical trials conducted with the participation of the population in women in menopausal age suggest that $8-\mathrm{PN}$ is a relatively safe for humans. The already mentioned study on humans, in which women received a single dose of 8-PN from 50 to $750 \mu \mathrm{g}$ showed good tolerance in patients [28]. The side effects, with the most common headache, gastrointestinal and allergic reactions did not result directly from the mechanism of action of 8-PN [38]. A similar lack of toxicity is shown in other aforementioned test on pharmacokinetics of 8-PN in women (increasing doses at monthly intervals) [30]. The beneficial effect in the menopause symptoms were demonstrated in 2006 study, which lasted 12 weeks and included 67 women. Patients in two examined groups received hop extract standarized on $100 \mu \mathrm{g}$ and $250 \mu \mathrm{g} 8-\mathrm{PN}$, identical to that of commercial preparation MenoHop. After 6 weeks, both doses resulted in a significant reduction in the modified Kupperman index (KI) and improved results in MENQOL questionnaire (menopause - specific quality of life) indexes, in which women assess the symptoms of menopause following appropriate point scales [7]. The improvement was primarily related to vasomotor symptoms (hot flashes, sweats). After 12 weeks, the trend remained, but it was not statistically significant, especially in case of higher dose of 8-PN. According to authors, the reason is the insufficient sample number of studied population [7]. Four years later, another study was conducted, in which 36 women were given the capsules with the hop extract. After 8 weeks, the women administered with 8 -PN began to receive placebo and vice versa. There were no side effects [22]. Before the change of drug, in both groups improved results were observed, but after the completion of the study, better results were obtained only among patients taking capsules with hops, which proved the superiority of 8-PN to placebo
[22]. In the last year, the results of the study, which was performed in Iran and involved 120 postmenopausal women, were announced. The first time hop extract was administered in tablet form. For 90 days, the participants were taking one tablet containing $500 \mathrm{mg}$ of extract standardized to $100 \mu \mathrm{g}$ 8-PN daily [39]. The Greene scale (for the characteristics of early vasomotor symptoms) and reports written by patient (observations concerning hot flashes) were used to assess the effectiveness of hops in the treatment of early complaints of menopause, which mainly involve hot flashes. The data were collected before the test, 4, 8 and 12 weeks [39]. The effectiveness of hop extract significantly exceeded the scores in the placebo group, after each assessment. Over time, the reduction of Greene scale outcomes was more visible after 12 weeks and reached nearly $90 \%$ of initial level. Similarly, there was a decrease in the number of hot flashes (about 95\% after 12 weeks). Similarly to earlier studies, there were no adverse effects [39]. This data seems to be promising, but it should be noted that the doses used in aforementioned studies in women are rather high (although cannot exclude to achieve them). As discussed above, hop extracts contain other flavonoids (like DMX or XN) which can be transformed to 8-PN. However, concerning the status of dietary supplements, it is not always possible to estimate the real amount of chemical compounds in them. Therefore, in order to credibly determine whether 8-PN can be effective in the treatment of menopause symptoms we need more studies, which would involve both high and lower doses of this compound in wider groups and in longer period.

\section{Is 8-PN safe for menopausal women?}

Although clinical studies have suggested the efficacy and safety of extracts of hops, it is still difficult to clearly confirm their positive effects, as compared to other PEs. Just as in the case of other PEs, there are still not enough studies evaluating the long-term effects of the administration of 8-PN in humans in last years. This is important in the light of already mentioned changes in uterus of animals induced by this compound. In particular a disturbing factor is their stimulating effect on the uterus, which may result in excessive proliferation of epithelial cells. The stimulation of uterus is of particular concern, since it can lead to endometrial hyperplasia and risk of carcinogenesis. The literature has described many cases of abnormal bleeding in postmenopausal women who took preparations 
containing PEs. Among them, there are four cases reported in Netherlands, that may be associated with undesirable effect of the components of hop [40]. The causes of such atypical bleeding can differ (eg. anatomical abnormalities, polyps or tumors), but these women attended the same gynecologist and were taking preparations MenoHop and MenoCool and bleeding subsided after going off these supplements. MenoHop contains an extract of hops with a declared value of $200 \mu \mathrm{g} 8$-PN and soy isoflavones. The MenoCool extract has a larger number of PEs in its composition, but it contains more than twice the amount of hop extract. Hence, the amount of 8-PN is also greater, although it is not specified by the manufacturer [40]. In case of one of the women, the myomas in the uterus was found, which can be compatible with a similar, already mentioned effect that occurred in rats exposed to high doses of 8-PN. 8-PN is characterized by a large volume of distribution, so it can accumulate in the tissue of the breast or uterus and consequently cause a strong estrogenic effect by genomic and non-genomic mechanism $[8,30]$.

The amount of plant raw material in dietary supplements with hops depends on the variety of hop plants, the place of growing, as well as climate, method of harvesting and processing [21]. The in $v i-$ tro and in vivo studies that will help determine the effectiveness, safety, pharmacokinetics, pharmacodynamics and also detailed qualitative and quantitative standardization in case of such strong substances like 8-PN are still necessary and essential. Studies should also include other hop flavonoids (XN, DMX, IX), which can be converted to 8-PN and increase its quantity and exposure to this compound. Interconversions of these prenylated flavonoids and their metabolism dependent on the individual variability (i.a. activity of CYP isoforms and intestinal microflora). This is important to avoid adverse effects, because women seek formulations that alleviate menopausal discomfort. The questionnaire survey conducted in Italian pharmacies showed that the majority of women buying preparations of PEs tend to take them on regular basis, mainly in order to reduce hot flashes. Moreover, $70 \%$ of them did not consult this with the doctor [41].

The complex and not fully understood mechanism of the action of PEs makes it difficult to determine how they can interfere with development of the reproductive system and sexual maturation. This is an important issue as young women often take the "enlargement of breasts" preparations that consist of hops and other botanical ingredients including hops
[5]. It is still not known if they contain 8-PN, and its uncontrolled accumulation in the body can affect the offspring. In addition to the prolonged selfmedication, potential side effects can be a result of variable contents of other PEs in the preparations. It is not known what are the possible mutual interactions of 8-PN, which is a potent agonist of ER, and acts as E2, though weaker.

\section{CONCLUSION}

Although 8-PN is a compound having a potent estrogenic activity and seems to be a good option of HTR replacement, it is difficult to evaluate the long-term effects in patient. The emerging clinical studies aimed at evaluation of the efficacy and safety of PEs to alleviate menopausal symptoms still show high demand for alternative treatments in relation to HTR. 8-PN is a highly potent compound with estrogen-like activity, thus the side-effects after a longterm use of hop extracts can be severe and appear early. It should be taken into account by the physicians who recommended those preparations, as well as by pharmacists, who should raise the awareness of patients searching for supplements which alleviate the menopause symptoms. It is still necessary to conduct further studies that will fully explain the scope of action of 8-PN on the human body, thus facilitating the selection of dose, and the duration of therapy. This will contribute to the most beneficial use of this compound in the treatment of postmenopausal symptoms with the minimized side effects.

\section{Abbreviations}

PE/PEs - Phytoestrogen(s), 8-PN - 8-Prenylnaringenin, 6-PN - 6-Prenylnaringenin, $\mathrm{XN}$ - Xanthohumol, DMX - Desmethylxanthohumol, IX - Isoxanthohumol, HTR - Hormone Replacement Therapy, ER/ERs - Estrogen receptor(s), E2 - 17- $\beta$-estradiol, ERE - Estrogen Responsive Element, CNS - Central Nervous System, SERM - Selective Estrogen Receptor Modulator, BMD - Bone mineral density, GnRH - Gonadotropin-releasing hormone, LH - Luteinizing hormone, FSH - Follicle-stimulating hormone, TST - tail skin temperature, KI - Kupperman index, MENQOL - Menopause - specyfic quality of life

Ethical approval: The conducted research is not related to either human or animal use.

Conflict of interest: Authors declare no conflict of interest. 


\section{REFERENCES}

1. Chadwick LR, Pauli GF, Farnsworth NR. The pharmacognosy of Humulus lupulus L. (hops) with an emphasis on estrogenic properties. Phytomedicine 2006; 13(1-2):119-131.

2. Zanoli P, Zavatti M. Pharmacognostic and pharmacological profile of Humulus lupulus L. J Ethnopharmacol 2008; 116(3):383-96. doi: http:// dx.doi.org/10.1016/j.jep.2008.01.011

3. Keiler AM, Zierau O, Kretzschmar G. Hop extracts and hop substances in treatment of menopausal complaints. Planta Med 2013; 79(7):576-9. doi: http://dx.doi.org/10.1055/s-0032-1328330

4. Milligan SR, Kalita JC, Heyerick A, Rong H, De Cooman L, De Keukeleire D. Identification of a potent phytoestrogen in hops (Humulus lupulus L.) and beer. J Clin Endocrinol Metab 1999; 84(6):2249-2252.

5. Milligan SR, Kalita JC, Pocock V, Van De Kauter V, Stevens JF, Deinzer ML et al. The endocrine activities of 8-prenylnaringenin and related hop (Humulus lupulus L.) flavonoids. J Clin Endocrinol Metab 2000; 85(12):4912-4915.

6. Bińkowska M, Dębski R, Paszkowski T, Sendrakowska M, Zgliczyński W. Guidelines for menopausal hormone therapy: Recommendations of the Polish Menopause and Andropause Society - state of knowledge as of December 2013. Prz Menopauzalny 2014; 13(1):1-12. doi: http:// dx.doi.org/10.5114/pm.2014.41078

7. Heyerick A, Vervarcke S, Depypere H, Bracke M, De Keukeleire D. A first prospective, randomized, double-blind, placebo-controlled study on the use of a standardized hop extract to alleviate menopausal discomforts. Maturitas 2006; 54(2):164-75.

8. Overk CR, Guo J, Chadwick LR, Lantvit DD, Minassi A, Appendino $G$ et al. In vivo estrogenic comparisons of Trifolium pratense (red clover) Humulus lupulus (hops), and the pure compounds isoxanthohumol and 8-prenylnaringenin. Chem Biol Interact 2008; 176(1):30-9. doi: http://dx.doi.org/10.1016/j.cbi.2008.06.005

9. Sobstyl M, Bednarek W, Tkaczuk-Włach J, Sobstyl J, Jakiel G. Vasomotor symptoms in meno- pause - diagnostic and treatment. Prz Menopauzalny $2011 ; 3: 254-259$.

10. Sobstyl M, Tkaczuk-Włach J, Sobstyl J, Jakiel G. Can non-hormonal therapy be effective in management of menopause symptoms? Prz Menopauzalny 2013; 1:92-96. doi: http://dx.doi. org/10.5114/pm.2013.33429

11. Połać I, Bobrowski M, Bijak M, Borowiecka M, Stetkiewicz T. Polyphenolic compounds and their supplementation in postmenopausal women. Prz Menopauzalny 2011; 2:157-162.

12. Sirotkin AV, Harrath AH. Phytoestrogens and their effects. Eur J Pharmacol 2014; 741:230-6. doi: http://dx.doi.org/10.1016/j.ejphar.2014.07.057

13. Kraszewska O, Nynca A, Kamińska B, Ciereszko R. Fitoestrogeny i występowanie, metabolizm i znaczenie biologiczne u samic. Post Biol Komórki 2007; 34(1):189-205.

14. Cheung AM, Chaudhry R, Kapral M, Jackevicius C, Robinson G. Perimenopausal and postmenopausal health. BMC Women's Health 2004; 4:23. doi: http://dx.doi.org/10.1186/1472-6874-4-S1-S23

15. Makara-Studzińska MT, Kryś-Noszczyk KM, Jakiel G. Epidemiology of the symptoms of menopause - an intercontinental review. Prz Menopauzalny 2014; 13(3):203-11. doi: http://dx.doi. org/10.5114/pm.2014.43827

16. Czarnecka-Iwańczuk M, Stanisławska-Kubiak M, Mojs E, Wilczak M, Samborski W. Menopause symptoms versus life satisfaction and self-esteem among women. Prz Menopauzalny 2012; 6:468473.

17. Putyński L, Janicka K. The role of hormone therapy in the lives of menopausal women. Prz Menopauzalny 2011; 6:457-463.

18. Dąbrowska J, Dąbrowska-Galas M, Naworska B, Wodarska M, Plinta R. The role of physical activity in preventing obesity in midlife women. Prz Menopauzalny 2015; 14(1):13-19. doi: http:// dx.doi.org/10.5114/pm.2015.49252

19. Christoffel J, Rimoldi G, Wuttke W. Effects of 8-prenylnaringenin on the hypothalamo-pituitary-uterine axis in rats after 3-month treatment. J Endocrinol 2006; 188(3):397-405. 
20. Bowe J, Li XF, Kinsey-Jones J, Heyerick A, Brain $\mathrm{S}$, Milligan $\mathrm{S}$ et al. The hop phytoestrogen, 8-prenylnaringenin, reverses the ovariectomy-induced rise in skin temperature in an animal model of menopausal hot flashes. J Endocrinol 2006; 191(2):399-405.

21. Krause E, Yuan Y, Hajirahimkhan A, Dong H, Dietz BM, Nikolic D et al. Biological and chemical standardization of a hop (Humulus lupulus) botanical dietary supplement. Biomed Chromatogr 2014; b28(6):b729-34. doi: http://dx.doi. org/10.1002/bmc.3177

22. Erkkola R, Vervarcke S, Vansteelandt S, Rompotti P, De Keukeleire D, Heyerick A. A randomized, double-blind, placebo-controlled, cross-over pilot study on the use of a standardized hop extract to alleviate menopausal discomforts. Phytomedicine 2010; 17(6):389-96. doi: http://dx.doi. org/10.1016/j.phymed.2010.01.007

23. Yazaki K, Sasaki K, Tsurumaru Y. Prenylation of aromatic compounds, a key diversification of plant secondary metabolites. Phytochemistry 2009; 70(15-16):1739-45. doi: http://dx.doi. org/10.1016/j.phytochem.2009.08.023

24. Schaefer O, Hümpel M, Fritzemeier KH, Bohlmann R, Schleuning WD. 8-Prenylnaringenin is a potent ER alpha selective phytoestrogen present in hops and beer. J Steroid Biochem Mol Biol 2003; 84(2-3):359-360.

25. Hümpel M, Isaksson P, Schaefer O, Kaufmann U, Ciana P, Maggi A et al. Tissue specificity of 8-prenylnaringenin: protection from ovariectomy induced bone loss with minimal trophic effects on the uterus. J Steroid Biochem Mol Biol 2005; 97(3):299-305.

26. Roelens F, Heldring N, Dhooge W, Bengtsson M, Comhaire F, Gustafsson JA et al. Subtle side-chain modifications of the hop phytoestrogen 8-prenylnaringenin result in distinct agonist/antagonist activity profiles for estrogen receptors alpha and beta. J Med Chem 2006; 49(25):7357-7365.

27. Böttner M, Christoffel J, Wuttke W. Effects of long-term treatment with 8-prenylnaringenin and oral estradiol on the GH-IGF-1 axis and lipid metabolism in rats. J Endocrinol 2008; 198(2):395-401. doi: http://dx.doi.org/10.1677/ JOE-08-0127
28. Rad M, Hümpel M, Schaefer O, Schoemaker RC, Schleuning WD, Cohen AF et al. Pharmacokinetics and systemic endocrine effects of the phyto-oestrogen 8-prenylnaringenin after single oral doses to postmenopausal women. Br J Clin Pharmacol 2006; 62(3):288-296.

29. Nilsson S, Kela SM, Treuter E, Tujague M, Thomsen J, Andersson GR et al. Mechanisms of estrogen action. Physiological Reviews 2001; 81(4):1535-1565.

30. van Breemen RB, Yuan Y, Banuvar S, Shulman LP, Qiu X, Alvarenga RF et al. Pharmacokinetics of prenylated hop phenols in women following oral administration of a standardized extract of hops. Mol Nutr Food Res 2014; 58(10):1962-9. doi: http://dx.doi.10.1002/mnfr.201400245

31. Liu M, Hansen PE, Wang G, Qiu L, Dong J, Yin $\mathrm{H}$ et al. Pharmacological profile of xanthohumol, a prenylated flavonoid from hops (Humulus lupulus). Molecules 2015; 20(1):754-79. doi: http:// dx.doi.org/10.3390/molecules20010754

32. Nikolic D, Li Y, Chadwick LR, Grubjesic S, Schwab P, Metz P et al. Metabolism of 8-prenylnaringenin, a potent phytoestrogen from hops (Humulus lupulus), by human liver microsomes. Drug Metab Dispos 2004; 32(2):272-9.

33. Possemiers S, Bolca S, Grootaert C, Heyerick A, Decroos K, Dhooge $\mathrm{W}$ et al. The prenylflavonoid isoxanthohumol from hops (Humulus lupulus L.) is activated into the potent phytoestrogen 8-prenylnaringenin in vitro and in the human intestine. J Nutr 2006; 136(7):1862-1867.

34. Possemiers S, Heyerick A, Robbens V, De Keukeleire D, Verstraete W. Activation of proestrogens from hops (Humulus lupulus L.) by intestinal microbiota; conversion of isoxanthohumol into 8-prenylnaringenin. J Agric Food Chem 2005; 53(16):6281-6288.

35. Yuan Y, Qiu X, Nikolić D, Chen SN, Huang K, Li $G$ et al. Inhibition of human cytochrome P450 enzymes by hops (Humulus lupulus) and hop prenylphenols. Eur J Pharm Sci 2014; 53:55-61. doi: http://dx.doi.org/10.1016/j. ejps.2013.12.003

36. Zierau O, Hauswald S, Schwab P, Metz P, Vollmer G. Two major metabolites of 8-prenylnaringenin 
are estrogenic in vitro. J Steroid Biochem Mol Biol 2004; 92(1-2):107-110.

37. Rimoldi G, Christoffel J, Wuttke W. Morphologic changes induced by oral long-term treatment with 8-prenylnaringenin in the uterus, vagina, and mammary gland of castrated rats. Menopause 2006; 13(4):669-677.

38. Hajirahimkhan A, Dietz BM, Bolton LB. Botanical modulation of menopausal symptoms: Mechanisms of action? Planta Med 2013; 79(7):538-553.

39. Aghamiri V, Mirghafourvand M, MohammadAlizadeh-Charandabi S, Nazemiyeh H. The effect of hop (Humulus lupulus L.) on early meno- pausal symptoms and hot flashes: a randomized placebo-controlled trial. Complement Ther Clin Pract 2015; 12: S1744-3881(15)00039-0. doi: http://dx.doi.org/10.1016/j.ctcp.2015.05.001

40. van Hunsel FPAM, Kampschöer PHNM. Postmenopauzaal bloedverlies en voedingssupplementen. Ned Tijdschr Geneeskd 2012; 156:A5095.

41. Girardi A, Piccinni C, Raschi E, Koci A, Vitamia $B$, Poluzzi E et al. Use of phytoestrogens and effects perceived by postmenopausal women: result of a questionnaire-based survey. BMC Complement Altern Med 2014; 14:262. doi: http://dx.doi. org/10.1186/1472-6882-14-262

\title{
8-Prenylnaringenina z szyszek chmielu (Humulus lupulus L.) - panaceum na menopauzę?
}

\author{
ALDONA MINECKA*, MARIA ZYCH, ILONA KACZMARCZYK-SEDLAK
}

Katedra Farmakognozji i Fitochemii

Uniwersytet Śląski w Katowicach

Wydział Farmaceutyczny z Oddziałem Medycyny Laboratoryjnej w Sosnowcu

ul. Jagiellońska 4

41-200 Sosnowiec

*autor, do którego należy kierować korespondencję: aldona.minecka@med.sum.edu.pl

\section{Streszczenie}

8-Prenylonaryngenina (8-PN) jest najsilniejszym znanym fitoestrogenem. Jej głównym źródłem są żeńskie kwiatostany (szyszki) chmielu Humulus lupulus L. W odróżnieniu od innych fitoestrogenów, 8-PN charakteryzuje się większą aktywnością i silniejszym powinowactwem wobec podtypu $\alpha$ receptorów estrogenowych (ER), dlatego może stanowić skuteczny zamiennik hormonalnej terapii zastępczej (HTZ). Badania z udziałem kobiet w okresie postmenopauzalnym dowiodły skuteczności 8-PN zwłaszcza w łagodzeniu uderzeń gorąca, jednak silna stymulacja macicy może prowadzić do efektów ubocznych (np. krwawień) i zwiększać ryzyko nowotworzenia. Preparaty z ekstraktem z chmielu mają status suplementów, co utrudnia precyzyjne określenie stosowanych dawek i prowadzi do niekontrolowanego samoleczenia. Artykuł prezentuje bieżącą wiedzę na temat 8-PN i omawia potencjalne ryzyko związane z używaniem chmielu do lagodzenia objawów menopauzy.

Słowa kluczowe: 8-prenylonaryngenina, chmiel, fitoestrogeny, uderzenia goraca, suplementy diety, skutki uboczne 